\title{
The Clinical Association of Autosomal Dominant Polycystic Kidney Disease and Renal Cell Carcinoma
}

\author{
Wesley Lane ${ }^{1}$, Evan Lacefield ${ }^{1}$, Ruc Tran ${ }^{2}$, Werner de Riese ${ }^{\mathbf{1}}$ \\ Department of Urology, Texas Tech University Health Science Center, Lubbock, Texas, USA ${ }^{1}$ \\ Department of Pathology, Texas Tech University Health Science Center, Lubbock, Texas, USA ${ }^{2}$ \\ E-mail: Wesley.Lane@ttuhsc.edu \\ Received April 21, 2011; revised May 22, 2011; accepted May 29, 2011
}

\begin{abstract}
Autosomal Dominant Polycystic Kidney Disease (ADPKD) is not currently considered to be a risk factor for renal cell carcinoma (RCC). We present data from our institution demonstrating incidence of RCC with ADPKD above the incidence rate for RCC in the general population, as well as that in patients with end-stage renal disease (ESRD). The discussion relates our findings in the context of the current literature including recent case reports published in this entity.
\end{abstract}

Keywords: Autosomal Dominant Polycystic Kidney Disease, Renal Cell Carcinoma, Incidence

\section{Introduction}

Since Walters and Brasch first described renal cell carcinoma occurring in ADPKD in 1934, 50 more cases have been reported in the literature $[1,2]$. Most cases of RCC in ADPKD have been unilateral, however, 12 cases of bilateral RCC in this patient population have been reported since the first in 1954 by Borski and Kimbrough $[2,3]$. While premalignant changes have been shown to occur in ADPKD, clinical research has not supported an association between RCC and ADPKD until Hajj et al. suggested an increased incidence of RCC in patients with ADPKD [4-6]. Current literature recognizes that RCC tends to occur at a younger age, and is more often bilateral in ADPKD patients, however, there is currently no recognized increased risk of RCC amongst ADPKD patients compared to the general population [7,8]. This paper presents cases of RCC in ADPKD from our institution between 2000 and 2010 .

\section{Methods and Materials}

All institutional cases of either unilateral or bilateral nephrectomy between 2000 and 2010, 177 cases in total, were reviewed for the pathologic diagnosis of ADPKD. Cases resulting from other causes of cystic disease such as acquired cystic disease, benign cysts, autosomal recessive polycystic kidney disease, tuberous sclerosis, and Von-Hippel Lindau disease were excluded. Six cases of ADPKD were identified in this patient cohort (Table 1). The presence of renal cell carcinoma was reviewed, yielding two patients who had both ADPKD and RCC, as well as one with renal papillary adenoma. Figure 1 shows pathologic specimens of ADPKD with RCC.

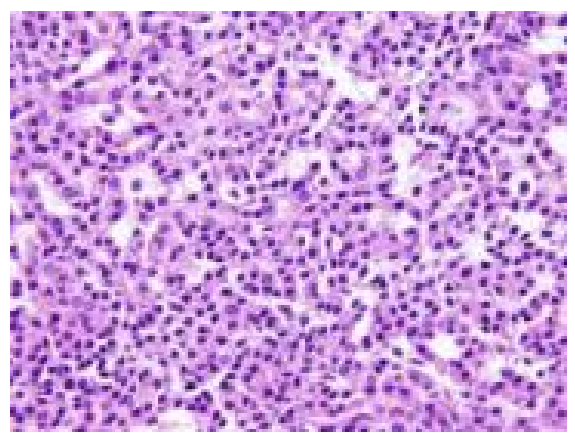

(a)

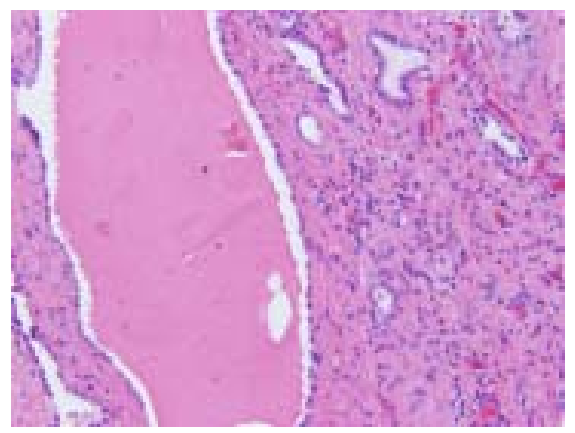

(b)

Figure 1. (a) A representative example of a polycystic kidney composed of cysts of different sizes and dysplastic ducts; H\&E staining; (b) Renal cell carcinoma with polymorphic nuclei removed from tumor cluster located in polycystic kidney via nephrectomy; H \& E staining. 
Table 1. RCC amongst patients with ADPKD.

\begin{tabular}{|c|c|c|c|c|c|c|c|}
\hline \multirow{3}{*}{$\begin{array}{c}\text { Table } 1 \\
1\end{array}$} & \multicolumn{7}{|c|}{ Patients with Autosomal Dominant Polycystic Kidney Disease } \\
\hline & \multirow{2}{*}{$\begin{array}{c}\text { Age/Sex } \\
64 / F\end{array}$} & \multirow{2}{*}{$\begin{array}{c}\begin{array}{c}\text { Date of } \\
\text { Nephrectomy }\end{array} \\
06 / 10\end{array}$} & \multirow{2}{*}{$\begin{array}{r}\text { Indication } \\
\text { Kidney Size }\end{array}$} & \multirow{2}{*}{$\begin{array}{c}\mathrm{HD}^{\mathrm{a}} \text { Prior to } \\
\text { Nephrectomy } \\
2.5 \mathrm{yrs}\end{array}$} & \multirow{2}{*}{$\begin{array}{l}\text { RCC Pathology } \\
\text { Bilateral Papil- } \\
\text { lary Adenomas }\end{array}$} & \multicolumn{2}{|c|}{$\begin{array}{c}\text { Carcinoma Diameter } \\
\text { L/R }\end{array}$} \\
\hline & & & & & & $0.4 \mathrm{~cm}$ & $0.4 \mathrm{~cm}$ \\
\hline 2 & $59 / \mathrm{M}$ & $05 / 10$ & $\begin{array}{l}\text { Renal } \\
\text { Calcification }\end{array}$ & $0^{\mathrm{b}}$ & - & - & - \\
\hline 4 & $41 / \mathrm{F}$ & $11 / 08$ & Kidney Size & 2 yrs & - & - & - \\
\hline 5 & $50 / \mathrm{F}$ & $06 / 07$ & Kidney Size & $1.5 \mathrm{yrs}$ & - & - & - \\
\hline 6 & $51 / \mathrm{M}$ & $05 / 07$ & Kidney Size & Unavailable & $\begin{array}{l}\text { Unilateral Clear } \\
\text { Cell Carcinoma }\end{array}$ & - & $3.5 \mathrm{~cm}$ \\
\hline
\end{tabular}

a. HD - Hemodialysis; b. Received living donor transplant prior to nephrectomy

A Pubmed search combining renal cell carcinoma and autosomal dominant polycystic kidney disease was performed which yielded 47 independent papers. These papers were reviewed and 50 case reports of $\mathrm{RCC}$ in ADPKD were identified, 12 with bilateral involvement.

\section{Results}

The data from our review show that 2 of 6 patients with ADPKD presented with overt RCC at time of nephrectomy, 1 with bilateral malignancies. In addition, subject 1 was found to have singular areas of papillary neoplasia identified in bilateral kidneys; each measuring $0.4 \mathrm{~cm}$. Microscopic examination of this tissue revealed lowgrade papillary renal cell carcinoma. According to the current WHO classification system, the only histologic distinguishing factor between papillary renal cell carcinoma (PRCC) and papillary adenoma is size. Currently, the WHO classification system defines papillary adenomas as epithelial lesions with a tubulopapillary architecture measuring less than $5 \mathrm{~mm}$ [9]. Although the areas of neoplasia in the latter patient meet the specifications of adenoma according to the WHO classification system, we include this patient in our study due to bilateral kidney involvement and characteristic histology of papillary renal cell carcinoma despite a $1 \mathrm{~mm}$ size discrepancy between papillary adenoma and papillary renal cell carcinoma. Specimen from subject 3 demonstrated 2 separated areas of clear cell RCC in the left kidney (1.1 $\mathrm{cm}$ and $0.55 \mathrm{~cm}$ ), and one clear cell $\mathrm{RCC}$ in the right kidney measuring $0.2 \mathrm{~cm}$. Specimen from subject 6 demonstrated a $3.5 \mathrm{~cm}$ clear cell $\mathrm{RCC}$ in the right kidney.

\section{Discussion}

The incidence of renal cell carcinoma is estimated to be 18.4 per 100000 in men and 9.5 per 100000 in women [10]. Between $70 \%$ and $80 \%$ of patients with spontaneous renal cell carcinoma are diagnosed as having clear cell type with the remainder having chromophilic, chromophobic, oncocytic, or papillary [11]. Cigarette smoking, obesity, chronic hemodialysis, and hypertension are considered risk factors for renal cell carcinoma $[12,13]$. The incidence of ADPKD is 1 in 6000 [14]. The incidence of end-stage renal disease due to ADPKD is 8.7 per 1000000 men and 6.9 per 1000000 million women in the United States [11]. End stage renal disease in patients with ADPKD account for $10 \%-15 \%$ of dialysis patients [15]. Historically, neither epidemiologic nor clinical retrospective studies have established a link between RCC and ADPKD [4]. The association between RCC and ADPKD remains controversial, and there is scarce literature available attempting to establish a link between these disorders [6]. Current literature states that there is no increased risk of RCC in patients with ADPKD despite presentation at a younger age and increased incidence of bilateral renal involvement [8]. The preoperative diagnosis of RCC in end-stage renal disease patients with ADPKD is cumbersome and difficult. Imaging studies such as ultrasound and computed tomography often fail due to the cystic degenerative changes of the kidneys. On the other hand, end-stage renal disease of any etiology is considered to be a risk factor for developing RCC. This makes finding a correlation between RCC and ADPKD difficult as it is often impossible to determine if a patient developed the malignancy as a primary result of ADPKD or due to the elevated risk associated with chronic hemodialysis in end-stage renal disease [16].

According to our literature search, 50 cases of RCC in ADPKD have been described in the literature, 12 of which were bilateral [2]. Table 2 lists 38 of these cases. These reports have shown that RCC presents in ADPKD with several unique characteristics: younger age at presentation, more likely to present with fever, and more likely to be bilateral, multicentric and sarcomatoid in type [5]. To date, there has been little evidence that the 
Table 2. Literature review: patients with ADPKD and RCC.

\begin{tabular}{|c|c|c|c|c|c|c|c|c|c|c|c|}
\hline Patient & Age/Sex & $\begin{array}{c}\text { RCC in- } \\
\text { volvement }\end{array}$ & $\begin{array}{c}\text { Year } \\
\text { Diagnosed }\end{array}$ & $\begin{array}{l}\text { HD } \\
\text { (yrs) }\end{array}$ & Citation & Patient & Age/Sex & $\begin{array}{c}\text { RCC in- } \\
\text { volvement }\end{array}$ & $\begin{array}{c}\text { Year } \\
\text { Diagnosed }\end{array}$ & $\begin{array}{l}\text { HD } \\
\text { (yrs) }\end{array}$ & Citation \\
\hline 1 & $69 / \mathrm{F}$ & Bilateral & 1998 & 16 & [17] & 20 & $39 / \mathrm{M}$ & Unilateral & 1977 & - & [5] \\
\hline 2 & $58 / \mathrm{M}$ & Unilateral & 2000 & 10 & [17] & 21 & $47 / \mathrm{F}$ & Unilateral & 1977 & - & [5] \\
\hline 3 & $69 / \mathrm{M}$ & Bilateral & 2002 & 15 & [17] & 22 & $62 / \mathrm{M}$ & Unilateral & 1977 & - & {$[5]$} \\
\hline 4 & 59/M & Bilateral & 2004 & 17 & [17] & 23 & $29 / F$ & Unilateral & 1978 & - & {$[5]$} \\
\hline 6 & $50 / \mathrm{M}$ & Unilateral & 2005 & 5 & [17] & 25 & $31 / \mathrm{F}$ & Unilateral & 1980 & - & [5] \\
\hline 7 & $66 / F$ & Unilateral & 2007 & 10 & [17] & 26 & $67 / F$ & Unilateral & 1980 & - & [5] \\
\hline 8 & $53 / \mathrm{M}$ & Unilateral & 2007 & 11 & [17] & 27 & $46 / \mathrm{M}$ & Unilateral & 1980 & - & {$[5]$} \\
\hline 9 & $65 / \mathrm{M}$ & Unilateral & 2005 & 11 & [17] & 28 & $40 / \mathrm{M}$ & Bilateral & 1981 & - & [5] \\
\hline 10 & $71 / \mathrm{M}$ & Unilateral & 2008 & 13 & [17] & 29 & $65 / F$ & Unilateral & 1987 & - & [5] \\
\hline 11 & $38 / \mathrm{M}$ & Unilateral & 1938 & - & {$[5]$} & 30 & $61 / \mathrm{F}$ & Bilateral & 1987 & - & {$[5]$} \\
\hline 13 & $46 / \mathrm{M}$ & Unilateral & 1943 & - & [5] & 32 & 59/M & Unilateral & 1988 & - & [5] \\
\hline 14 & 39/M & Bilateral & 1952 & - & [5] & 33 & $31 / \mathrm{M}$ & Unilateral & 1994 & - & [5] \\
\hline 15 & $37 / \mathrm{M}$ & Unilateral & 1957 & - & [5] & 34 & $44 / F$ & Unilateral & 1994 & - & [5] \\
\hline 16 & $65 / F$ & Unilateral & 1962 & - & [5] & 35 & $62 / \mathrm{F}$ & Unilateral & 1994 & - & [5] \\
\hline 17 & $32 / \mathrm{F}$ & Unilateral & 1969 & - & [5] & 36 & $58 / \mathrm{M}$ & Bilateral & 2004 & 14 & {$[2]$} \\
\hline 18 & $45 / F$ & Unilateral & 1972 & - & [5] & 37 & $60 / \mathrm{M}$ & Bilateral & 2004 & - & [18] \\
\hline 19 & $44 / \mathrm{M}$ & Bilateral & 1973 & - & [5] & 38 & $42 / \mathrm{F}$ & Bilateral & 2004 & - & [18] \\
\hline
\end{tabular}

cumulative incidence of RCC is increased in pts with ADPKD compared to the general population [7].

Hajj et al. demonstrated a prevalence rate of RCC of $8.3 \%$ in patients with ADPKD and Chronic Renal Failure. It increased to $12 \%$ in their patient population after 1 year of dialysis or kidney transplantation [6]. These findings along with an incidence of $50 \%$ in our patient population, even in a small study, indicate an increased risk of RCC in patients with ADPKD. Additionally, the propensity of these malignancies to present bilaterally and at a younger age compared to the general population also suggests an elevated risk in this patient population. This incidence of RCC is also far above that which is observed in ESRD patients with secondary acquired renal cystic disease (ARCD), a well documented risk factor for the development of RCC. The risk of developing ARCD increases with time spent on dialysis. For example, Ishikawa and coworkers found ARCD in 44\% of patients who had been receiving hemodialysis for less than 3 years but in $79 \%$ of those who had been receiving hemodialysis for a longer time [19]. Overall, eighty percent of patients with end-stage renal failure eventually develop acquired renal cystic disease, and $1 \%$ to $2 \%$ of this subgroup develops RCC over 10 years of follow-up. If no RCC has developed after 10 years with ARCD, the risk is considered almost zero [7]. In contrast, at least two of the three ADPKD patients with RCC in our study had not been on hemodialysis for more than three years prior to the diagnosis of $\mathrm{RCC}$, further suggesting a specific link between ADPKD and RCC in these patients.
Further research and studies are necessary to provide a better understanding of this important clinical issue. Should this link be confirmed, then early bilateral nephrectomy in ADPKD patients with end-stage renal disease should be recommended.

\section{References}

[1] W. Walters and W. F. Brasch, "Surgical Aspects of Polycystic Kidney," Surgical and Gynacological Obstetrics, Vol. 58, No. 3, 1934.

[2] Y. L. Chang, H. J. Chung and K. K. Chen, "Bilateral Renal Cell Carcinoma in a Patient with Autosomal Dominant Polycystic Kidney Disease," Journal of the Chinese Medical Association, Vol. 70, No.9, 2007, pp. 403-405. doi:10.1016/S1726-4901(08)70029-7

[3] A. A. Borski and J. C. Kimbrough, "Bilateral Renal Cell Carcinoma in Polycystic Kidney Disease, an Unique Case," Journal of Urology, Vol. 71 No. 5, 1954, pp. 677 681.

[4] J. R. Gregoire, V. E. Torres, K. E. Holley and G. M. Farrow, "Renal Epithelial Hyperplastic and Neoplastic Proliferation in Autosomal Dominant Polycystic Kidney Disease," American Journal of Kidney Diseases, Vol. 9 No. 1, 1987, pp. 27-38.

[5] D. S. Keith, V. E. Torres, B. F. King, H. Zincki and G. M. Farrow, "Renal Cell Carcinoma in Autosomal Dominant Polycystic Kidney Disease," Journal of the American Society of Nephrology, Vol. 4, No. 9, 1994, pp. 1661-1669.

[6] P. Hajj, et al., "Prevalence of Renal Cell Carcinoma in Patients with Autosomal Dominant Polycystic Kidney Disease and Chronic Renal Failure," Urology, Vol. 74, 
No. 3, 2009, pp. 631-634. doi:10.1016/j.urology.2009.02.078

[7] A. J. Wein, et al., "Campbell-Walsh Urology," 9th Edition, Elsevier Inc., Philidelphia, Vol. 2, pp. 1583-1588 and Vol.4, 2007, pp. 3323.

[8] L. Gomella, "The 5-Minute Urology Consult," Lippincott Williams and Wilkins, Philidelphia, PA, 2009.

[9] K. L. Wang, et al., "Renal Papillary Adenoma-A Putative Precursor of Papillary Renal Cell Carcinoma," Human Pathology, Vol. 38, No. 2, 2007, pp. 239-246. doi:10.1016/j.humpath.2006.07.016

[10] D. K. Espey, et al., "Annual Report to the Nation on the Status of Cancer, 1975-2004, Featuring Cancer in American Indians and Alaskan Natives," Cancer, Vol. 110, No. 10, 2007, pp. 2119-2152. doi: $10.1002 /$ cncr. 23044

[11] B. I. Rini, S. C. Campbell and B. Escudier "Renal Cell Carcinoma," Lancet, Vol. 28, No. 373, 2009, pp. 1119-1132. doi:10.1016/S0140-6736(09)60229-4

[12] R. P. Theis, S. M. Dolwick Grieb, D. Blurr, T. Siddiqui and N. R. Asal "Smoking, Environmental Tobacco Smoke, and Risk of Renal Cell Cancer: A Population-Based Case-Control Study," BMC Cancer, Vol. 8, No. 387, 2008, pp. 1-11.

[13] Y. Wang, X. Chen, Y. Song, B. Caballero and L. J. Cheskin, "Association between Obesity and Kidney Disease: A Systematic Review and Meta-Analysis," Kidney International, Vol. 73, No. 1, 2008, pp. 19-33. doi:10.1038/sj.ki.5002586

[14] P. A. Gabow, "Autosomal Dominant Polycystic Kidney Disease." New England Journal of Medicine, Vol. 329, No. 5, 1993, pp. 332-342. doi:10.1056/NEJM199307293290508

[15] K. Badani, A. K. Hemal and M. Menon, "Autosomal Dominant Polycystic Kidney Disease and Pain - A Review of the Disease from Aetiology, Evaluation, Past Surgical Treatment Options to Current Practice," Journal of Postgraduate medicine, Vol. 50, No. 3, 2004, pp. 222-226.

[16] Y. Kojima, S. Takahara, O. Miyake, N. Nonomura, A. Morimoto and H. Mori, "Renal Cell Carcinoma in Dialysis Patients: A Single Center Experience," International Journal of Urology, Vol. 13 No. 8, 2006, pp. 1045-1048. doi:10.1111/j.1442-2042.2006.01498.x

[17] H. Nishimura, "Renal Cell Carcinoma in Autosomal Dominant Polycystic Kidney Disease," American Journal of Kidney Disease, Vol. 54, No. 1, 2009, pp. 165-168. doi:10.1053/j.ajkd.2009.01.270

[18] A. Kapoor, et al., "Renal Cell Carcinoma in Autosomal Dominant Polycystic Kidney Disease,” European Journal of Radiology Extra, Vol. 51, No. 2, 2004, pp. 87-89. doi:10.1016/j.ejrex.2004.05.003

[19] I. Ishikawa, et al., "Development of Acquired Cystic Disease and Adenocarcinoma of the Kidney in Glomerulonephrotic Chronic Hemodialysis Patients," Clinical Nephrolgy, Vol. 14, No. 1, 1980, pp. 1-6. 